\title{
STUDI STABILITAS STATIS KAPAL PURSE SEINE DI KABUPATEN BONE SULAWESI SELATAN
}

\author{
Study of Purse Seiner Static Stability in Bone Regency South Sulawesi \\ Oleh : \\ Fina Fatwasari, St. Aisjah Farhum, Ilham Jaya \\ Departemen Perikanan/Program Studi Pemanfaatan Sumberdaya Perikanan, Universitas Hasanuddin, Indonesia \\ * Korespondensi:finasudarman@gmail.com
}

\begin{abstract}
The establishment of purse seiner in South Sulawesi, particularly in East TaneteRiattang districts, Bone regency, was built based on artisan habitude, the manufacture was done which did not base on naval architect calculation. This had implication to ship manufacturing which did not suitable with fishery ship standard that had determined. The purpose of this research is purse seiner static stability in Bone regency, particularly in East TaneteRiattang districts. Sample taking used purposive sampling method. The sample is purse seiner built in Bone District, the data retrieval of ship's main dimension calculating (LOA (Length Over All), LWL (Length Water Line), LBP (Length Between Perpendiculars), BOA (Breadth Over All), D (Depth), dand (Draft)), the obtained data was analyzed for getting hydrostatic value and ship stability. As a result, the purse seiner static stability in East TaneteRiattang districts, Bone regency, was on standard range value which had determined by IMO for fish ship stability. But,the main ship dimension ratio value's comparison still did not fulfill Ayodhya standard that means the main dimension size value still needs improvement so that fulfilling the standard with the result that the purse seiner movement could work optimally.
\end{abstract}

Key words: purse seine, ship dimensions, stability

\begin{abstract}
ABSTRAK
Pembangunan kapal Purse Seine di Sulawesi Selatan khususnya di Kecamatan Tanete Riattang Timur Kabupaten Bone dibangun berdasarkan kebiasaan pengrajin, pembuatannya dilakukan yang tidak berdasarkan perhitungan naval architect. Hal ini berimplikasi pada pembuatan kapal yang tidak sesuai standar kapal perikanan yang telah di tentukan.Tujuan dari penelitian ini untuk mengkaji kelayakan stabilitas statis kapal purse seine di Kabupaten Bone khususnya di KecamatanTanete Riattang Timur. Pengambilan sampel menggunakan metode purposive sampling, sampel yang diteliti merupakan kapal purse seine yang dibangun di Kabupaten Bone, dimana dilakukan pengambilan data pengukuran dimensi utama kapal (LOA (Length Over All), LWL (Length Water Line), LBP (Length Between Perpendiculars), BOA (Breadth Over All), D (Depth), dand (Draft)), data yang diperoleh dianalisis untuk mendapatkan nilai hidrostatis dan stabilitas kapal. Hasil dari penelitian stabilitas statis kapal purse Seine di KecamatanTanete Riattang Timur Kabupaten Bone berada dalam nilai kisaran standar yang telah ditetapkan IMO untuk stabilitas kapal ikan, namun pada perbandingan nilai rasio dimensi utama kapal masih belum memenuhi standar Ayodhya yang mengartikan bahwa nilai ukaran dimensi utamanya masih perlu perbaikan agar memenuhi standar sehingga olah gerak kapal mampu bekerja secara optimal.
\end{abstract}

Kata kunci:,dimensi kapal, purse seine, stabilitas 


\section{PENDAHULUAN}

Pembangunan kapal perikanan di sulawesi selatan khususnya di Kecamatan Tanete Riattang Timur Kabupaten Bone dibangun berdasarkan kebiasaan pengrajin, pembuatannya dilakukan tanpa adanya perencanaan desain dan konstruksi. Hal ini berimplikasi pada pembuatan kapal yang tidak sesuai standar.

Kesempurnaan pembangunan kapal dapat ditunjukkan dengan melihat cara gerak kapal pada saat dioperasikan, yaitu harus sanggup mengapung di permukaan air dengan kestabilan yang baik, dapat bergerak dengan kecepatan yang bervariasi, olah gerak yang baik serta cukup kuat untuk bertahan terhadap pengaruh gelombang pada cuaca yang buruk.

Stabilitas kapal dapat diartikan sebagai kemampuan sebuah kapal untuk dapat kembali ke posisi semula (tegak) setelah menjadi miring akibat bekerjanya gaya dari luar maupun dari dalam kapal tersebut atau setelah mengalami momen temporal (Fyson 1985). Stabilitas kapal terkait distibusi muatan dan perhitungan nilai lengan penegak (Gz).

Keberhasilan operasi penangkapan pada usaha perikanan pada usaha perikanan tangkap sangat bergantung pada kestabilan kapal pada saat beroperasi di perairan. Berdasarkan hal tersebut, penelitian ini dianggap penting dilakukan untuk mengetahui stabilitas kapal pukat cincin (purse seine) di Kabupaten Bone.

\section{METODE}

Penelitian ini dilakukan d Kecamatan Tanete Riattang timur Kabupaten Bone Sulawesi Selatan dengan mengambil sampel kapal Purse seine dengan metode purposive sampling dan simuliasi numerik, yaitu pengambilan sampel yang dilakukan secara sengaja sesuai dengan persyaratan atau ciri sampel yang diperlukan, dimana data yang diambil pada sampel kapal purse seine yaitu dengan mengukur (LOA, BOA, D dan LWL) yang nantinya nilai rasio yang diperoleh akan di bandingkan dengan standar nilai acuan yang dibuat oleh Ayodhyoa (1972), dan juga akan diolah dengan bantuan aplikasi perkapalan yaitu untuk mendesain kapal, menggambar general arrangement, lines plan, parameter hidrostatis, dan parameter stabilitas.

\section{HASIL DAN PEMBAHASAN}

\section{Dimensi Utama Kapal Purse Seine}

Dari hasil pengukuran secara langsung di lokasi penelitian, diperoleh ukuran dimensi kapal dari sampel purse seine dapat dilihat pada Tabel 1.

Tabel 1 Nilai dimensi utama kapal sampel di Kabupaten Bone

\begin{tabular}{ccccc}
\hline Kapal & $\mathbf{L}(\mathbf{m})$ & $\mathbf{B}(\mathbf{m})$ & $\mathbf{D}(\mathbf{m})$ & $\mathbf{d}(\mathbf{m})$ \\
\hline Sampel & 19.81 & 4.31 & 1.84 & 1.28 \\
\hline
\end{tabular}

Berdasarkan data primer yang diperoleh dilapangan, nilai dimensi ukuran utama kapal purse seine yang diukur di Kecamatan Tanete Riattang Timur Kabupaten Bone yaitu dengan panjang 19.81 meter; lebar 4.31 meter; tinggi1. 84 meter; dan draft berkisar antara 1.28 meter. Dari hasil nilai dimensi utama maka diperoleh juga nilai rasio dimensi utama.

Tabel 2 Nilai rasio dimensi kapal

\begin{tabular}{lccc}
\hline \multicolumn{1}{c}{ Kapal } & L/B & L/D & B/D \\
\hline Sampel & 4.5963 & 10.7663 & 2.3424 \\
Ayodhya, (1972) & $4.30-4.50$ & $10.00-11.00$ & $2.10-2.15$ \\
\hline
\end{tabular}

Pada sampel kapal purse seine yang diteliti di Kecamatan Tanete Riattang Timur Kabupaten Bone, dapat dilihat belum sesuai dengan pernyataan Ayodhyoa (1972). Dalam hal ini 
nilai rasio L/B kapal purse seine yang diteliti lebih besar dari nilai standar yang ditetapkan, sesuai dengan standar Ayodhyoa (1972) yaitu dengan nilai rasio L/B 4.596 dan 4.594. Nilai rasio L/B kapal yang lebih besar dari standar akan mengakibatkan mengecilnya tahanan gerak kapal sehingga akan mempengaruhi kecepatan kapal. Untuk penyesuaian terhadap rasio standar, perlu dilakukan penambahan nilai B pada sampel kapal dengan tetap memperhatikan nilai $L$ untuk memberikan stabilitas yang baik pada kapal.

Untuk nilai rasio L/D, dari sampel kapal purse seine di Kecamatan Tanete Riattang Timur Kabupaten Bone, sudah sesuai dengan yang disarankan oleh Ayodhyoa (1972), yaitu dengan nilai rasio L/D sebesar 10.76, yang mengartikan bahwa kekuatan memanjang kapal sampel sudah baik. Hal ini disebabkan oleh nilai $D$ yang cukup mampu mengimbangi nilai $L$ sehingga kapal akan lebih kuat terhadap gerakan bending (lengkung) yang berarah keatas dan kebawah. Seperti yang dikatakan Ayodhyoa (1972) bahwa, jika nilai depth (D) diperbesar maka diperoleh hal-hal positif antara lain longitudinal strength (kekuatan memanjang) akan membaik.

Nilai rasio dimensi utama B/D yang diperoleh pada kapal purse seine di Kabupaten Bone tidak sesuai dengan angka yang ditetapkan oleh Ayodhoyoa (1972) dimana nilai B/D lebih besar dari yang disarankan. Menurut Nurdin (2010) hal ini terjadi dikarenakan nilai depth (D) cukup rendah sehingga tidak sesuai dengan lebar kapal. Pada kapal purse seine yang diteliti stabilitasnya akan naik namun longitudinal strength (kekuatan mendorong) kapal akan melemah, dimana hal ini sesuai dengan pernyataan Ayodhyoa (1972) bahwa jika nilai B/D membesar maka stabilitas akan membaik namun longitudinal strength (kekuatan mnedorong) kapal akan memburuk. Untuk penyesuaian terhadap nilai standar rasio B/D maka perlu dilakukan penambahan nilai depth (D) dengan penyesuaian terhadap nilai B untuk mendapatkan longitudinal strength (kekuatan mendorong) kapal yang baik dengan stabilitas yang baik.

Ketidak sesuaian nilai-nilai rasio kapal purse seine yang diteliti dengan nilai standar Ayodhyoa (1972), disebabkan oleh pembuatan kapal yang tidak berdasarkan perhitungan naval architect. Selain itu, kurangnya pengetahuan pengrajin kapal mengenai kesesuaian ukuran kapal dengan alat tangkap yang digunakan akan mempengaruhi penentuan ukuran utama kapal yang akan dibuat.

\section{Kapasitas Kapal Purse Seine(Tonnage)}

Kapasitas (tonnage) kapal adalah suatu besaran yang menunjukkan kapasitas atau volume ruangan-ruangan yang tertutup dan dianggap kedap air yang berada di dalam kapal. Kapasitas kapal dapat ditinjau dari nilai gross tonnage (GT). Kesesuaian nilai panjang (L) dan GT kapal purse seine sampel dapat dilihat pada Tabel 3.

Tabel 3 Kapasitas kapal purse seine (tonnage)

\begin{tabular}{ccccc}
\hline \multirow{2}{*}{ Kapal } & \multirow{2}{*}{$\mathbf{L}(\mathbf{m})$} & \multirow{2}{*}{ GT } & \multicolumn{2}{c}{ Ayodhya (1972) } \\
\cline { 4 - 5 } & & & $\mathrm{L}(\mathrm{m})$ & $\mathrm{GT}$ \\
\hline Sampel & 19.81 & 26.285 & $<20$ & $5-50$ \\
\hline
\end{tabular}

Berdasarkan table nilai GT di Kecamatan Tanete Riattang Timur Kabupaten Bone sebesar 26.28 GT. Menurut Ayodhyoa (1972) kapal yang memiliki nilai L (panjang) kurang dari 20 meter $(\mathrm{L}<20$ meter) nilainya berkisar antara $5-50$ GT sedangkan kemampuan untuk kapal yang memiliki nilai $L$ (panjang) lebih dari 20 meter ( $L>20$ meter) memiliki nilai GT berkisar antara 50 90 GT. Oleh karena itu, nilai gross tonnage (GT) kapal purse seine dari sampel berdasarkan Tabel 3 telah sesuai dengan nilai standar GT Ayodhyoa (1972).

\section{Rancangan Umum (General Arrmgement)}

Rancangan umum (general arrangement) merupakan gambar yang menunjukkan secara umum kelengkapan ruang kapal yang dapat dilihat dari atas dan samping kapal. Rancangan umum dari sampel kapal purse seine yang diteliti dapat dilihat pada Gambar 1. Sampel tampak samping dapat dilihat dari sudut samping kapal secara berurutan dari buritan ke haluan, yaitu:

1. Dapur

2. Ruang ABK

3. Ruang Kemudi

4. Ruang Peralatan. Ruang Peralatan yang juga berfungsi sebagai tempat Penyimpanan gabus yang berisi es dan hasil tangkapan. 


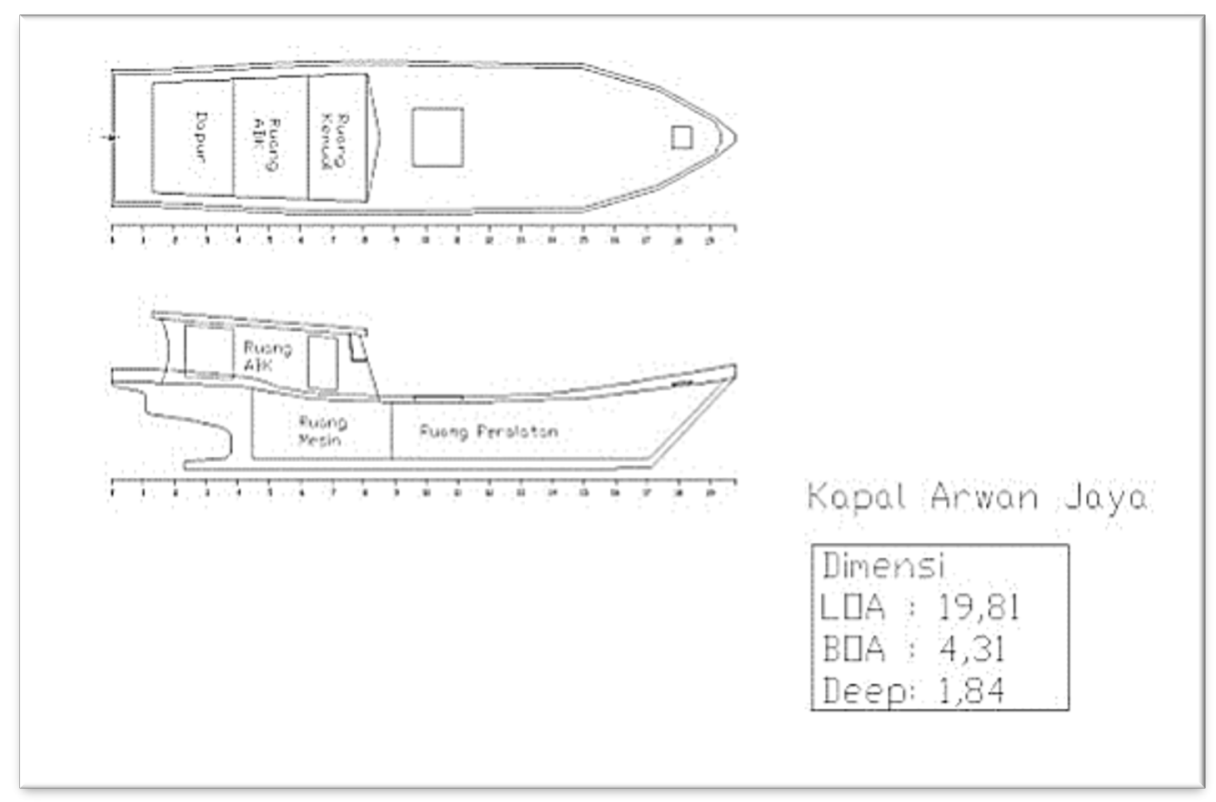

Gambar 1 Rancangan umum kapal sampel

Pada gambar General Arrangement menunjukkan bahwa kapal sampel memiliki satu bangunan di atas kapal yang terdiri dari ruang kemudi, dapur dan ruang $A B K$, satu ruangan mesin yang terletak di bagian buritan kapal, ruang peralatan yang terletak di bagian tengah yang berfungsi sebagai tempat penyimpanan es, hasil tangkapan dan peralatan yang menunjang proses berlayar, kapal ini tidak memiliki palka tetapi memiliki pintu palka yang berfungsi sebagai tempat keluar masuk ABK saat melakukan persiapan. Adapun hasil tangkapan yang di dapatkan oleh nelayan digunakan gabus atau styrofoam untuk penyimpanan ikan, gabus di simpan di dalam ruang perlengkapan ataupun di atas deck depan ruang kemudi.

\section{Rencana Garis (Lines Plan) Kapal Purse Seine}

Rencana garis (lines plan) merupakan gambar dalam bentuk rencana garis kapal yang dibuat pada masing-masing garis air dan ordinat mengunakan aplikasi maxsurf. Rencana garis (lines plan) kapal purse seine yang diteliti secara umum dibagi menjadi beberapa ordinat membujur sepanjang badan kapal dengan jarak setiap ordinat, yaitu sepanjang satu meter. Kapal purse seine yang diteliti juga dibagi atas lima garis air (water line) yang sama, yakni mulai garis air terendah (base line) hingga garis air tertinggi (draft). Gambar rencana garis (lines plan)kapal pada setiap garis air dan ordinat yang diproyeksikan kedalam tiga buah gambar, yaitu:

1. Body plan adalah gambar rencana garis kapal dari arah depan (irisan melintang kapal tampak depan).

2. Profile plan merupakan gambar bentuk irisan memanjang kapal tampak samping.

3. Half breadth plan merupakan gambar irisan melintang setengah lebar kapal tampak atas. Pada gambar ini juga ditunjukkan buttock line, yaitu garis sejajar dengan center line.

Hasil penggambaran lines plan kapal purse seine dapat dilihat pada Gambar 2. Gambar tersebut meunjukkan bentuk badan kapal pada bagian haluan berbentuk $\mathrm{V}$ yang dimana bentuk haluan ini berbentuk ramping. Hal ini dapat memudahkan kapal untuk membelah massa air di depan kapal saat melaju sehingga kapal dapat melaju dengan kecepatan tinggi. Pada bagian buritan kapal berbentuk $U$, bentuk ini memungkinkan kapal memiliki tahanan yang tidak telalu besar, kemampuan untuk membelah gelombang yang cukup baik, dan memungkinkan volume ruang yang maksimum. 

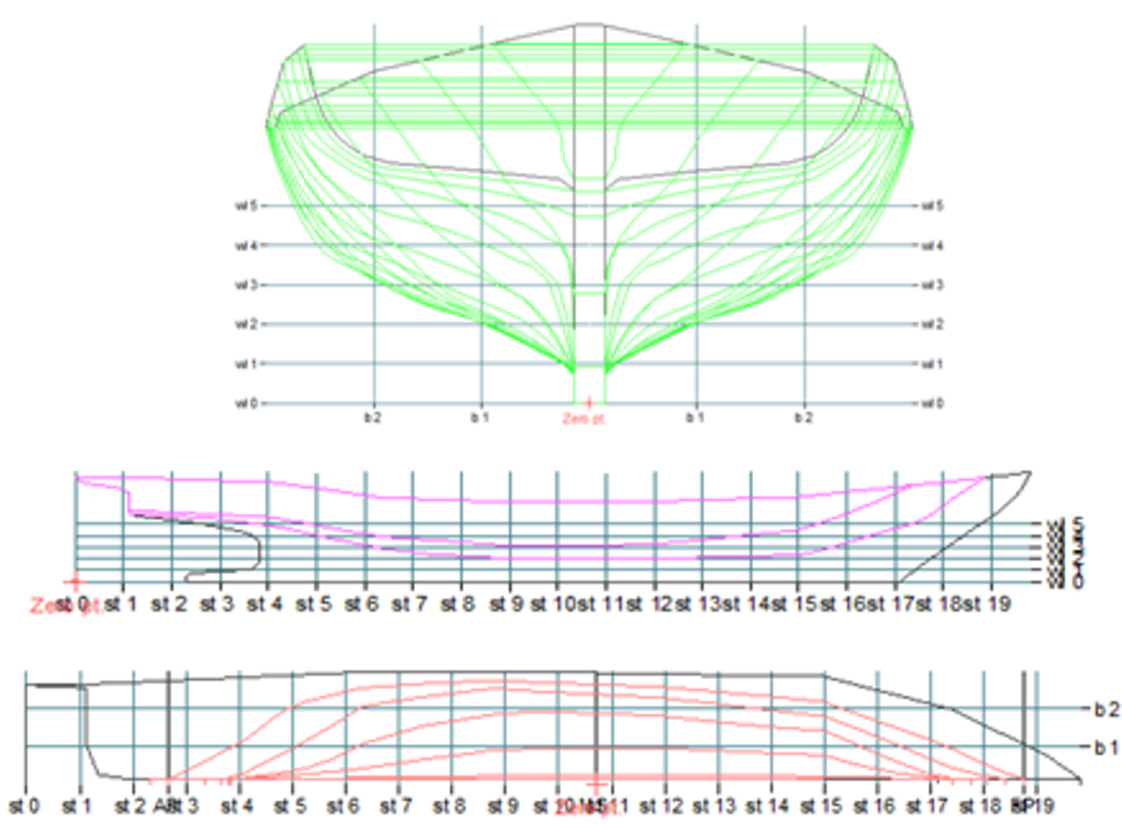

Gambar 2 Lines plane Kapal Arwan Jaya

\section{Parameter Hidrostatis Kapal Purse Seine}

Parameter hidrostatis merupakan suatu ukuran atau nilai yang menggambarkan kapal secara statis serta kelayakan desain sebuah kapal. Parameter hidrostatis untuk kapal purse seine yang diteliti dapat dilihat pada Tabel 4.

Tabel 4 Parameter hidrostatis Kapal Arwa Jaya

\begin{tabular}{|c|c|c|c|c|c|c|}
\hline No. & Parameter & WL 1 & WL 2 & WL 3 & WL 4 & WL 5 \\
\hline 1 & Volume displacement $\left(\mathrm{m}^{3}\right)$ & 865398,24 & 2997921,18 & 7948110,82 & 15921142,38 & 26667422,63 \\
\hline 2 & Ton displacement (ton) & 0,8968 & 3,067 & 8,132 & 16,32 & 27,33 \\
\hline 3 & Water area $(A w)\left(m^{2}\right)$ & 48675,01 & 147754,58 & 291753,21 & 421559,90 & 537816,08 \\
\hline 4 & Midship area (Ao) $\left(\mathrm{m}^{2}\right)$ & 114017,61 & 241103,47 & 405789,76 & 554990,56 & 694492,02 \\
\hline 5 & Ton Per Centimeter (TPC) & 0,050 & 0,151 & 0,299 & 0,432 & 0,551 \\
\hline 6 & Coefficient block $(\mathrm{Cb})$ & 0,685 & 0,300 & 0,257 & 0,283 & 0,321 \\
\hline 7 & Coefficient prismatic $(\mathrm{Cp})$ & 1,022 & 0,769 & 0,676 & 0,653 & 0,634 \\
\hline 8 & Coefficient waterplane $(\mathrm{Cw})$ & 0,854 & 0,663 & 0,636 & 0,670 & 0,725 \\
\hline 9 & Coefficient midship (Co) & 0,670 & 0,390 & 0,380 & 0,446 & 0,514 \\
\hline 10 & $\begin{array}{l}\text { Longitudinal Centre } \\
\text { Buoyancy }(\mathrm{LCB})(\mathrm{cm})\end{array}$ & $-84,96$ & $-15,52$ & 4,92 & 3,77 & $-6,51$ \\
\hline 11 & Jarak KB $(\mathrm{cm})$ & 11,54 & 28,58 & 46,42 & 62,79 & 78,27 \\
\hline 12 & Jarak BM $(\mathrm{cm})$ & 5,57 & 71,39 & 212,23 & 270,04 & 264,07 \\
\hline 13 & Jarak KM $(\mathrm{cm})$ & 17,11 & 99,97 & 258,65 & 332,83 & 342,34 \\
\hline 14 & Jarak BML $(\mathrm{cm})$ & 8558,85 & 4920,33 & 3548,98 & 3004,14 & 2872,97 \\
\hline 15 & Jarak KML (cm) & 8570,39 & 4948,91 & 3595,39 & 3066,93 & 2951,24 \\
\hline
\end{tabular}

Untuk menilai kelayakan sebuah desain kapal, salah satunya dapat dilihat dari nilai coefficient of fineness dari kapal tersebut. Dibawah ini merupakan tabel yang menunjukkan nilai coefficient of fineness kapal purse seine yang diteliti pada water line setinggi draft dan coefficient of fineness menurut Ayodhyoa (1972). Nilai tersebut disajikan pada Tabel 5. 
Tabel 5 Nilai coefficient of fineness

\begin{tabular}{lcccc}
\hline \multirow{2}{*}{ Kapal } & \multicolumn{4}{c}{ Coefficient of fineness } \\
\cline { 2 - 5 } & $\mathrm{Cb}$ & $\mathrm{Cp}$ & $\mathrm{Cm}$ & $\mathrm{Cw}$ \\
\hline Kapal Arwan Jaya & 0,325 & 0,630 & 0,515 & 0,731 \\
Ayodhyoa (1972) & $0.57-0.68$ & $0.67-0.75$ & $0.76-0.94$ & $0.91-0.95$ \\
\hline
\end{tabular}

Volume displacement $(\mathrm{V})$ merupakan nilai yang menunjukkan volume badan kapal yang nilainya sama dengan nilai volume air laut yang dipindahkan saat kapal terbenam pada posisi water line tertentu, nilai Volume displacement (V) pada sampel kapal purse seine yang diteliti semakin bertambah besar sesuai dengan posisi water line. Nilai ini berfungsi untuk mengestimasi volume muatan yang dapat ditampung oleh kapal.

Ton displacement $(\Delta)$ merupakan nilai yang menunjukkan beban/massa badan kapal pada posisi water line tertentu, pada sampel kapal purse seine yang diteliti nilai Ton displacement $(\Delta)$ bertambah besar sesuai dengan posisi water line. Besarnya nilai ton displacement berbanding lurus dengan volume displacement sehingga kurva volume displacement selalu bersinggungan dengan kurva ton displacement. Semakin besar nilai water area maka kapal memiliki kemampuan menerima distribusi muatan secara horisontal.

Water area (Aw) merupakan nilai yang menunjukkan luas area kapal pada posisi water line tertentu secara horisontal longitudinal. Nilai Water area (Aw) pada sampel kapal purse seine yang diteliti mengalami peningkatan dari WL 1 ke WL 5, Semakin besar nilai water area maka kapal memiliki kemampuan menerima distribusi muatan secara horisontal.

Midship area $(A \otimes)$ merupakan nilai yang menunjukkan luas irisan melintang dari bagian tengah kapal pada posisi water line tertentu. Sama hal nya dengan ilai $(A w)$ nilai $(A \otimes)$ pada sampel kapal purse seine yang diteliti mengalami peningkatan dari WL 1 ke WL 5 . Nilai ini menunjukkan tempat yang tepat untuk penempatan palka pada bagian midship.

Ton Per Centimeter (TPC) merupakan nilai yang menunjukkan jumlah beban/massa yang dibutuhkan oleh kapal untuk merubah draft sebesar $1 \mathrm{~cm}$. Nilai ini berfungsi untuk mengestimasi beban/massa maksimum yang dapat di toleransi oleh kapal.

Coefficient block $(\mathrm{Cb})$ merupakan perbandingan antara isi carene dengan isi suatu bak dengan panjang (L), lebar (B), dan tinggi (D). Nilai yang dapat mendeskripsikan tingkat kegemukan suatu kapal adalah $\mathrm{Cb}$ (Coefficient block). Nilai ini bergerak dari 0 - 1. Semakin mendekati nilai 1 , kapal dikatakan semakin gemuk dan sebaliknya dikatakan ramping jika mendekati nilai 0 . Untuk nilai $(\mathrm{Cb})$ pada kapal sampel tidak sesuai dengan standar yang ditetapka oleh Ayodhyoa, dimana hasil nilai yang diperoleh lebih kecil dari nilai ketetapan, yang berarti keseluruhan sampel memiliki lambung kapal yang langsing, sehingga menguntungkan dalam kecepatan kapal.

Coefficient of prismatic $(\mathrm{Cp})$ adalah perbandingan antara volume badan kapal yang berada dibawah permukaan air dengan volume sebuah prisma dengan luas penampang midship area dan panjang kapal. Nilai coefficient of prismatic pada water line 5 untuk semua kapal purse seine yang diteliti tidak sesuai dengan nilai standard menurut Ayodhyoa (1972). Dimana nilai CP kapal sampel kurang dari Standar yang ditetapkan. Nilai CP mempengaruhi tahanan gerak kapal, semakin besar nilai CP maka semakin besar nilai tahanan gerak kapal begitupun sebaliknya, maka untuk semua kapal sampel memiliki tahanan gerak yang kecil.

Coefficient of waterplane (Cw) merupakan besarnya luas area penampang membujur tengah kapal dibanding dengan 4 persegi panjang yang mengelilingi luas area tersebut. Nilai coefficient of waterplane pada water line 5 untuk semua kapal kapal purse seine yang diteliti memiliki nilai yang hampir mendekati nilai ketetapan coefficient of waterplane menurut Ayodhyoa (1972). Hal ini membuktikan bahwa bentuk penampang garis air yang mendekati bentuk empat persegi, sehingga kapal sampel tersebut memiliki kestabilan yang masih baik.

Coefficient of midship $\left(\mathrm{C}_{\otimes}\right)$ merupakan perbandingan luas antara penampangan gading besar yang terendam air dengan luas suatu penampang yang lebarnya $B$ dan tinggi D. Nilai coefficient of midship pada kapal sampel tidak sesuai dengan standar Coefficient of midship menurut Ayodhyoa (1972), karena nilainya kurang dari standar yang ditetapkan, hal ini mengartikan bahwa kapal sampel memiliki bentuk lambung yang relatif berbentuk $V$. 
Nilai Longitudinal Centre Bouyancy (LCB) pada tabel hidrostatis untuk sampel menunjukkan nilai pada WL 2 bergerak naik dan pada WL 3 mulai bergerak turun sampai pada WL 5 .

Nilai KM, BM, dan KB pada tabel hidrostatis untuk kapal sampel menunjukkan bahwa nilai untuk jarak titik KM, BM, dan KB dari WL 1 - WL 5 semakin besar. Jarak titik apung (KB) memiliki nilai yang semakin besar dengan bertambahnya tinggi water line (Draft).

Nilai KML dan BML pada tabel hidrostatis untuk sampel menunjukkan bahwa nilai tersebut dari WL 1 - WL 5 semakin menurun.

\section{Stabilitas}

Perhitungan nilai $\mathrm{GZ}$ atau lengan pengembali/kopel merupakan bagian yang sangat penting dalam pembahasan mengenai penentuan stabilitas. Hal tersebut berfungsi untuk menghindari masuknya air ke dalam kapal. Kurva GZ menunjukkkan hubungan lengan pengembali GZ dengan berbagai macam sudut kemiringan Fyson (1985).

Stabilitas kapal sampel dianalisis menggunakan aplikasi Maxsurf dan menghasilkan kurva dan nilai lengan penegak (GZ). Kurva GZ kapal sampel dapat dilihat pada Gambar 3.

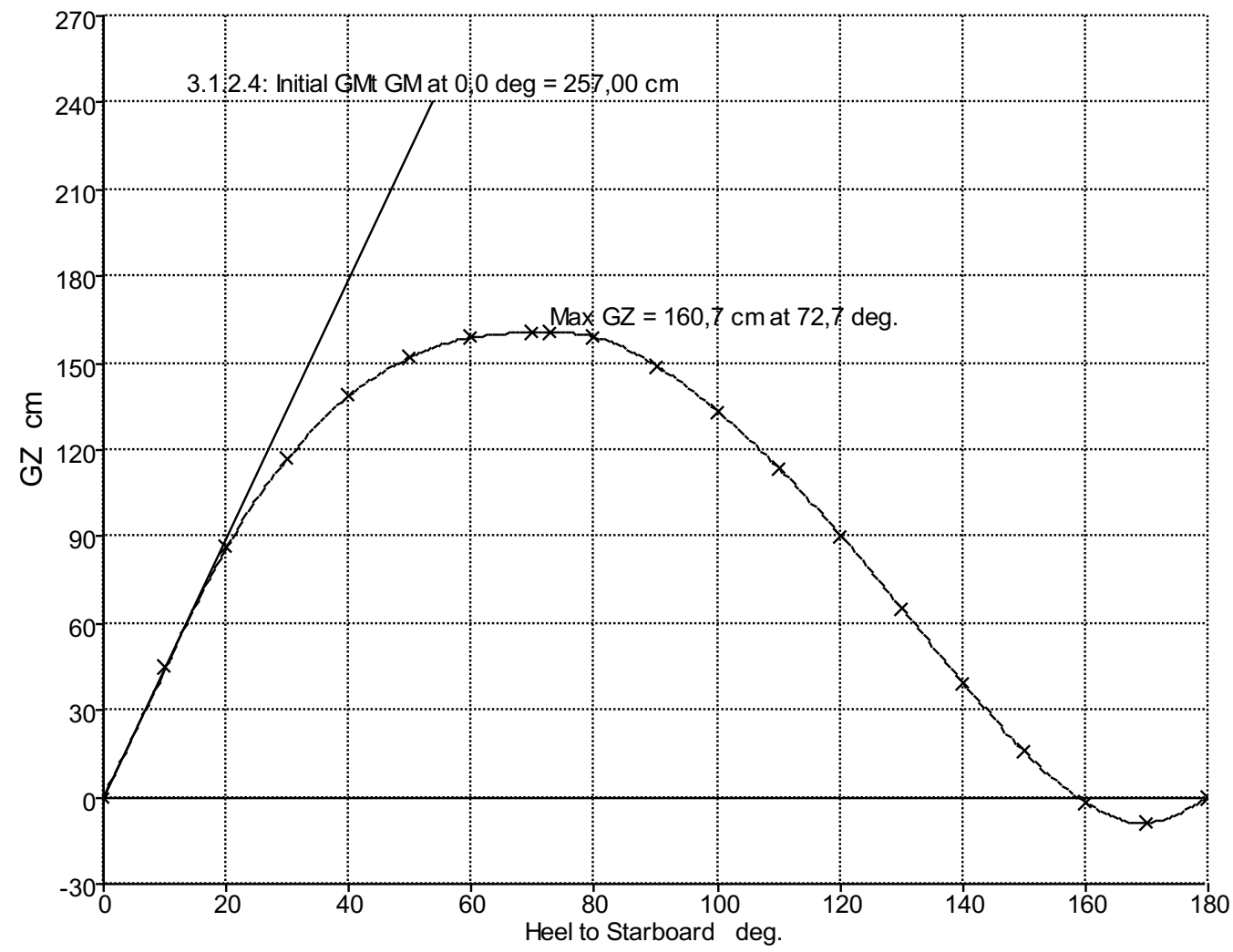

Gambar 3 Kurva GZ kapal sampel

Kriteria stabilitas kapal sampel yang dianalisis menggunakan aplikasi Maxsurf dapat dilihat dari perbandingan nilai lengan penegak GZ dengan nilai standar IMO seperti yang ditunjukkan pada Tabel 6.

Tabel 6 Nilai kriteria stabilitas kapal sampel

\begin{tabular}{cccc}
\hline Kriteria IMO & Value & Units & Sampel 1 \\
\hline Area 0 to 30 & 315,130 & $\mathrm{~cm} . \mathrm{deg}$ & 1913,205 \\
Area 0 to 40 & 515,660 & $\mathrm{~cm} . \mathrm{deg}$ & 3199,655 \\
Area 30 to 40 & 171,890 & $\mathrm{~cm} . \mathrm{deg}$ & 1286,450 \\
Max GZ at 30 or greater & 20,00 & $\mathrm{Cm}$ & 160,70 \\
Angle of maximum GZ & 25,0 & Deg & 72,7 \\
Initial GMt & 15,00 & $\mathrm{Cm}$ & 257,00 \\
\hline
\end{tabular}


Berdasarkan kurva stabilitas diketahui bahwa nilai GZ pada kapal sampel cenderung meningkat pada sudut oleng rendah $\left(0^{\circ}-40^{\circ}\right)$. Kurva tersebut menunjukkan bahwa lengan penegak GZ yang dihasilkan oleh kapal sampel adalah positif, yang berarti bahwa kapal mampu untuk kembali ke posisi semula setelah mengalami keolengan. Hal ini sesuai dengan pernyataan Tailor (1977) bahwa pada kondisi penuh (sarat maksimum) dihasilkan lengan kapel (righting arm) GZ positif yang mampu mengembalikan kapal ke posisi semula.

Nilai kriteria stabilitas kapal sampel dapat dilihat pada Tabel 6. Berdasarkan Tabel 6 nilai kriteria kapal sampel terhadap standar nilai minimum yang ditetapkan IMO diketahui bahwa kapal sampel telah memenuhi standar atau lebih besar dari nilai standar yang dipersyaratkan IMO. Hasil stabilitas kapal sampel menunjukkan bahwa lengan penegak GZ memiliki nilai lebih besar dibandingkan nilai minimum yang diterapkan oleh IMO.

Untuk memperoleh stabilitas yang baik, luas areal kurva GZ untuk luas areal sampai dengan $30^{\circ}$ tidak boleh kurang dari $315,130 \mathrm{~cm}$.deg, luas areal sampai $40^{\circ}$ tidak boleh kurang dari 515,660 $\mathrm{cm}$. deg, dan luas areal antara $30^{\circ}$ sampai dengan $40^{\circ}$ tidak boleh kurang dari $515,660 \mathrm{~cm}$. deg. Selain itu, kapal juga tidak boleh memiliki sudut oleng untuk lengan penegak GZmax tidak boleh lebih dari $30^{\circ}$, dan untuk nilai lengan penegak $G Z_{\max }$ tidak boleh kurang dari $20 \mathrm{~cm}$ serta tinggi metacenter tidak boleh kurang dari $15 \mathrm{~cm}$.

\section{SIMPULAN}

Berdasarkan hasil penelitian mengenai stabilitas statis kapal Purse Seine di kecamatan Tanete Riattang Timur Kabupaten Bone bahwa kapal sampel telah memenuhi kriteria kelayakan stabilitas yang baik sesuai dengan standar yang telah ditetapkan IMO untuk stabilitas kapal ikan. Namun masih perlu dilakukan perbaikan terhadap desain kapal utamanya pada beberapa nilai ukuran dimensi utama kapal sehingga mampu menghasilkan olah gerak kapal yang optimal dan sesuai standar kapal purse seine yang di tetapkan oleh Ayodhya (1972).

\section{DAFTAR PUSTAKA}

Ayodhyoa AU. (1972). Suatu Pengenalan Kapal Ikan. Bogor (ID): Fakultas Perikanan dan Ilmu Kelautan, Institut Pertanian Bogor.

Fyson J. (1985). Design of Fishing Vessel. England (UK): FAO-Fishing News Book, Ltd.

IMO-MSC.267(85). (2008): Adoption of the international code on intact stability, 2008 (2008 IS Code).

Nurdin HS. (2010). Studi kesesuaian desain dan konstruksi kapal purse seine di Kelurahan Tana Lemo Kecamatan Bontobahari Kabupaten Bulukumba. Skripsi. Fakultas IImu Kelautan dan Perikanan. Universitas Hasanuddin. Makassar. 